\title{
Testing of the insect pest control fungus Beauveria bassiana in grass shrimp Palaemonetes pugio*
}

\author{
Fred J. Genthner, Steven S. Foss, William S. Fisher
}

U.S. Environmental Protection Agency, Environmental Research Laboratory, 1 Sabine Island Drive, Guli Breeze, Florida 32561, USA

\begin{abstract}
Embryos, larvae and adult grass shrimp Palaemonetes pugio were exposed to spores of the insect-control fungus Beauveria bassiana. Conidiospores attached to embryos held by gravid females and remained with the egg mass for at least $6 \mathrm{~d}$. In the first experiment where individual developing embryos contained in test tubes were exposed to conidiospores of $B$. bassiana, 2 of the 75 embryos became infected and died, and a third was abnormal at hatch. In Expt 2, a repeat experiment, no adverse effects were observed. In subsequent experiments, attempts were made to increase the probability of infection or abnormal development for embryos exposed to B. bassiana. Strategies for these attempts included lowering the salinity, adding a carbon source for the fungus to the test water, or rendering embryos free of potentially protective symbiotic bacteria with an antibacterial agent. All attempts were unsuccessful in promoting infection or abnormal development. B. bassiana did not cause any adverse effects during shrimp larval development. In adult shrimp lethal infections only occurred in specimens injected with either conidiospores or blastospores of $B$. bassiana.
\end{abstract}

KEY WORDS: Beauveria bassiana Palaemonetes pugio Biological control/nontarget effects

\section{INTRODUCTION}

Insect-pathogenic fungi are receiving renewed attention as biological control agents particularly in cases where the insect pest is not effectively controlled by chemical pesticides (Osborne \& Landa 1990) or where the use of chemical pesticides poses a significant risk to either human health or the environment (Ferron 1978, McCoy 1990).

The fungus Beauveria bassiana has the potential to be a cost-effective insect biocontrol agent (Khachatourians 1986). Although not registered in the USA as a microbial pesticide, the U.S. Environmental Protection Agency is currently reviewing submissions for registering strains of $B$. bassiana for this purpose (U.S. EPA, Office of Pesticides and Toxic Substances, pers. comm.).

Concerns about possible environmental impacts of Beauveria bassiana arise because successful suppres-

- Contribution No. 879, Environmental Research Laboratory, U.S. EPA, Gulf Breeze sion of target pests requires either the broadcast application of large amounts of spores or a point-source inoculation and subsequent induction of a fungal epizootic. The finding that this broad host-range fungus can infect beneficial insects (Donegan \& Lighthart 1989, James \& Lighthart 1994) has heightened concern about its potential to cause adverse environmental effects. Contributing to this concern is the recent work of Genthner \& Middaugh (1992) and Middaugh \& Genthner (1994) who showed that B. bassiana can cause adverse effects on animals outside the class Insecta. These investigators adapted an existing chemical toxicity and teratogenicity test to assess potential adverse effects of $B$. bassiana on developing embryos of the inland silverside fish Menidia beryllina. Various adverse effects were observed including rupture of the chorion, developmental defects and death.

Virulence of Beauveria bassiana is dependent on a variety of factors including attachment, production of toxins and enzymes, and the condition of the host (Weiser 1982). Consequently, B. bassiana strains can possess different host specificities (Ferron 1978, McCoy 
1990). Thus, we felt additional studies that examined the effects of $B$. bassiana on other nontarget animals were warranted.

Fungus disease is more important in populations of aquatic invertebrates than is bacterial infection (Johnson 1983, Sparks 1985, Sindermann 1990). Unlike bacteria, fungi can cause abrupt and catastrophic epizootics in wild crustacean populations (Johnson 1983). The effect of Beauveria bassiana on nontarget crustaceans has previously been studied (Genthner et al. 1994). However, only juvenile Mysidopsis bahia were used in a static acute $96 \mathrm{~h}$ test. In the present study we tested the effect of $B$. bassiana spores on embryos, juveniles and adult grass shrimp Palaemonetes pugio.

\section{MATERIALS AND METHODS}

Cultivation of fungi and recovery of spores. Beauveria bassiana-grasshopper strain $(\mathrm{GH})$, an isolate of Mycotech Corporation ", was obtained from M. Goettel, Agriculture Canada Research Station, Lethbridge, Alberta, Canada.

Spore densities were determined using a hemocytometer. Viable spore counts were performed by diluting the spores in sterile distilled water containing $0.03 \%$ Triton X-100 (Union Carbide Chemicals and Plastics Co., Inc., Indianapolis, IN, USA) and spreading the dilutions onto glucose-yeast extract-basal salts agar (GYBS; Boucias et al. 1988) plates with a bent glass rod. Plates were incubated at $25^{\circ} \mathrm{C}$, and fungal colonies were counted after $5 \mathrm{~d}$.

Corn earworm Helicoverpa zea were exposed to Beauveria bassiana by dipping 2 nd instar worms into a concentrated conidiospore suspension. Five exposed worms were placed in a petri dish containing approximately $3 \mathrm{ml}$ of a sterile diet consisting of ground raw pinto beans, $14 \mathrm{~g}$; wheat germ, $10 \mathrm{~g}$; torula yeast, $6.3 \mathrm{~g}$; casein $5.0 \mathrm{~g}$; agar, $2.3 \mathrm{~g}$; and distilled water, $135 \mathrm{ml}$. Plates were incubated at $25^{\circ} \mathrm{C}$. Three days after exposure, dead worms displayjng external conidiogenesis were either stored frozen at $-80^{\circ} \mathrm{C}$ in $20 \%$ glycerol or homogenized in sterile water. A loopful of the homogenate was streaked onto a GYBS + nalidixic acid ( $\mathrm{Nx}$, $0.5 \mathrm{mg} \mathrm{ml}^{-1}$ ) plate. Isolated colonies of $B$. bassiana were selected to produce conidiospores on $\mathrm{Nx}$-free GYBS for subsequent exposure experiments.

After 6 to 8 d, conidiospores produced on GYBS were harvested by scraping the confluent mycelial mats with a sterile spatula. Conidia were suspended in

\footnotetext{
- Mention of tradenames or source of commercial products does not imply endorsement by the U.S. Environmental Protection Agency
}

sterile sea water by gentle aspiration in a hand-held tissue homogenizer at a density of approximately $1 \times$ $10^{8}$ spores $\mathrm{ml}^{-1}$ This concentrated stock was used for embryo and larval exposures within 4 h of preparation. A concentrated stock of approximately $2.5 \times 10^{8}$ spores $\mathrm{ml}^{-1}$, prepared in the above manner, was used to inject adult shrimp

Blastospores were produced in liquid culture as described by Bidochka et al. (1987). Blastospores were washed twice in sterile saline $(0.64 \%)$ solution and suspended to a final density of approximately $2.5 \times$ $10^{8} \mathrm{ml}^{-1}$, before being injected into adult shrimp.

Beauveria bassiana was recovered from exposed embryos, larvae and adult shrimp by washing them (twice in $100 \mathrm{ml}$ sterile water) to remove the spores carried over in water from the exposure tubes. Tissues were then homogenized and dilutions spread onto the surface of GYBS + Nx plates.

Bacteria on the chorion were enumerated by spreading dilutions of embryo homogenates onto the surface of NYGS agar plates. NYGS agar medium was made with sea water $(10 \%)$ and contained (per liter): nutrient broth media, $4 \mathrm{~g}_{i} \mathrm{KH}_{2} \mathrm{PO}_{4}, 0.5 \mathrm{~g}$; yeast extract, $0.5 \mathrm{~g}$; glycerol, $3 \mathrm{ml}$; and agar, $15 \mathrm{~g}$. The $\mathrm{pH}$ of the medium was adjusted to 7.5 before sterilization in an autoclave.

Embryo tests. Grass shrimp Palaemonetes pugio were collected and maintained, and shrimp embryo tests were performed as described by Fisher \& Foss (1993). Briefly, single embryos, at the blastospore/tissue cap stage (age 2 to 4 d after oviposition), were randomly placed into glass tissue culture tubes containing $6 \mathrm{ml}$ of filtered $(0.22 \mu \mathrm{m})$ sea water at salinities of $2,5,10$ or $20 \pm 0.5 \%$. Tubes were incubated for $12 \mathrm{~d}$ at $27^{\circ} \mathrm{C}$ with slow shaking $(60 \mathrm{rpm})$. Individual embryos were examined daily with an inverted microscope for stage of development, viability and extent of fungal growth on the chorion. Embryo development was determined according to the criteria established by Wilson (1985).

For embryo exposures a stock suspension of Beauveria bassiana conidiospores was diluted in sea water to attain approximate densities of $10^{6}, 10^{5}$ and $10^{4}$ spores $\mathrm{ml}^{-1}$. Six $\mathrm{ml}$ of these suspensions were added to each exposure tube. A heat-killed control was prepared by sterilizing a conidiospore suspension $\left(\mathrm{ca} 1 \times 10^{6} \mathrm{ml}^{-1}\right)$ in an autaclave $\left[20 \mathrm{~min}, 15 \mathrm{lb} \mathrm{in}^{-2}\left(=10^{5} \mathrm{~Pa}\right)\right]$. The design for Expts 1 and $2 \mathrm{~A}$ yielded 5 treatments, a no-exposure control, a 'heat-killed' control and three 10 -fold dilutions of conidiospores with 25 replicate embryos for each treatment. Expt $2 \mathrm{~B}$ comprised only 2 treatments, a noexposure control and a single conidiospore density with 10 replicate embryos for each treatment.

In Expt 3 the effect of an added carbon source in the embryo test water was examined by adding melezitose $\left(15 \mathrm{mg}^{-1}\right)$ to a conidiospore suspension (approximately $10^{6}$ spores $\mathrm{ml}^{-1}$ ) before distribution into the 
tubes. In this experiment, 4 treatment groups (25 replicates per group) that included 3 controls ('no spores/no melezitose', 'spores/no melezitose', 'no spores/melezitose') and 1 experimental treatment ('spores/melezitose') were employed.

Tests in Expt 4 were performed on embryos that were rendered bacteria-free. Embryos were incubated for $24 \mathrm{~h}$ at $27^{\circ} \mathrm{C}$ in sea water with and without $\mathrm{Nx}$ (0.5 $\mathrm{mg} \mathrm{l}^{-1}$ ). Embryos, 25 per treatment, were thoroughly rinsed in sterile sea water and aseptically placed in tubes containing $6 \mathrm{ml}$ of sterile sea water. Controls groups consisted of 'no spores/untreated embryos', 'spores/untreated embryos' and 'no spores/ Nx treated embryos'. The experimental treatment was 'spores/Nx treated embryos'. A stock spore suspension (60 1 l) was added to each tube resulting in a final spore density of $10^{6} \mathrm{ml}^{-1}$. After $9 \mathrm{~d}$ of incubation, 3 embryos were taken from the 'spores/untreated' tubes and from the 'spores/Nx treated' tubes. Each group of 3 embryos was pooled and homogenized in $3 \mathrm{ml}$ of sterile sea water. Dilutions of the homogenates were plated onto NYGS agar medium to confirm that the Nx-treated embryos remained free of culturable bacteria.

Larval test. Tests were conducted as described by McKenney \& Neff (1979). Larvae were obtained from gravid females maintained in the laboratory. The larvae were collected approximately $24 \mathrm{~h}$ after hatching. The test used 4 treatments, a heat-killed conidiospore control and 3 conidiospore densities of approximately $10^{6}, 10^{5}$ and $10^{4}$ conidiospores $\mathrm{ml}^{-1}$. Each treatment was performed in triplicate with 10 larvae in $11.4 \mathrm{~cm}$ diameter glass culture bowls. Larvae were incubated for $10 \mathrm{~d}$ at $25^{\circ} \mathrm{C}$ with a photoperiod of $14 \mathrm{~h}$ light and $10 \mathrm{~h}$ darkness. Each culture bowl contained $150 \mathrm{ml}$ of sea water at a salinity of $20 \%$. Larvae were fed freshly hatched Artemia salina nauplii daily. Every third day larvae were transferred to clean culture bowls containing fresh sea water $(20 \%$ ) and re-exposed to the appropriate density of conidiospores. Daily records of mortalities and infections were maintained until metamorphosis to post-larvae occurred. Significance between treatments was determined using a 1-way ANOVA (SAS Institute Inc. 1985).

Adult tests. Adult shrimp were exposed to Beauveria bassiana by addition of conidiospores to the test water or through intrahemocaelic injection of conidiospores and blastospores. Exposure via the test water was accomplished by placing 6 adult shrimp in each of 2 small, aerated aquaria containing $3 \mathrm{l}$ of sea water at $20 \%$ salinity. One aquarium served as the uninoculated control and another was inoculated with conidiospores to a density of approximately $10^{6} \mathrm{ml}^{-1}$. Flake tropical fish food was added daily. After 24 h shrimp were transferred to aquaria containing fresh sea water and the treated aquaria were reinoculated with spores to the original density. After 48 and 72 h, half the water in each aquarium was replaced with fresh sea water. Shrimp were observed daily for mortalities; the experiment was terminated after $7 \mathrm{~d}$.

In a separate experiment to determine the persistence of conidiospores adhering to embryos, 6 gravid females were placed into a small aerated aquarium containing 31 of sea water at $20 \%$ salinity and $23{ }^{\circ} \mathrm{C}$. The aquarium was inoculated with Beauveria bassiana conidiospores to a density of ca $10^{6} \mathrm{ml}^{-1}$. After $4 \mathrm{~h}$ the shrimp were transferred to a $60 \mathrm{l}$ aquarium equipped with a flow-through, filtered $(30 \mu \mathrm{m})$, sea water delivery system maintained at a flow rate of $1 \mathrm{l} \mathrm{min}^{-1}$. During incubation the salinity ranged from 18 to $22 \%$ and the temperature varied from 21 to $24^{\circ} \mathrm{C}$. A single gravid female shrimp was removed from the aquarium immediately and at 24, 48, 72 and $144 \mathrm{~h}$. Oviposited embryos were removed $(N=100)$, separated and placed into a sterile ground glass homogenizer. The eggs were homogenized in $2 \mathrm{ml}$ of sterile distilled water containing $0.03 \%$ Triton $\mathrm{X}-100$. Numbers of $B$. bassiana conidiospores in the homogenates were determined by plate count on GYBS + Nx.

Injected conidiospore and blastospore dosages $(2.0 \mu \mathrm{l}$ of Beauveria bassiana containing $5.0 \times 10^{5}$ spores) were delivered with a $1 \mathrm{cc}$ tuberculin syringe equipped with a 25-gauge needle and mounted on a microinjector pump. Shrimp were injected under the carapace at the posterior margin of the cephalothorax. Controls were injected with either $2.0 \mu \mathrm{l}$ of sterile saline-solution or $2.0 \mu \mathrm{l}$ of a filtrate produced by passing the conidiospore stock suspension through a $0.22 \mu \mathrm{m}$ filter.

Injected shrimp, 15 or 20 per treatment, were held in small, aerated aquaria for 2 h before surviving shrimp were transferred to static holding tanks. Water temperature and salinity were maintained at ca $23^{\circ} \mathrm{C}$ and $20 \%$, respectively. Shrimp were observed daily for mortality. Moribund shrimp were either examined microscopically as a fresh-squash of the internal organs or processed for histological examination.

Histological procedures. Some embryos and moribund shrimp were fixed for ca $48 \mathrm{~h}$ in Davidson's solution (Shaw \& Battle 1957), decalcified for $6 \mathrm{~h}$ in Cal-Ex ${ }^{\circledR *}$, dehydrated, embedded in paraffin and sectioned at $6 \mu \mathrm{m}$. Sections were stained with Harris' hematoxylin and eosin (Luna 1968).

\section{RESULTS}

\section{Embryo tests}

Embryos of Palaemonetes pugio were exposed to conidiospores of Beauveria bassiana in 4 separate experiments. Expt 1 provided the only data that indicated 

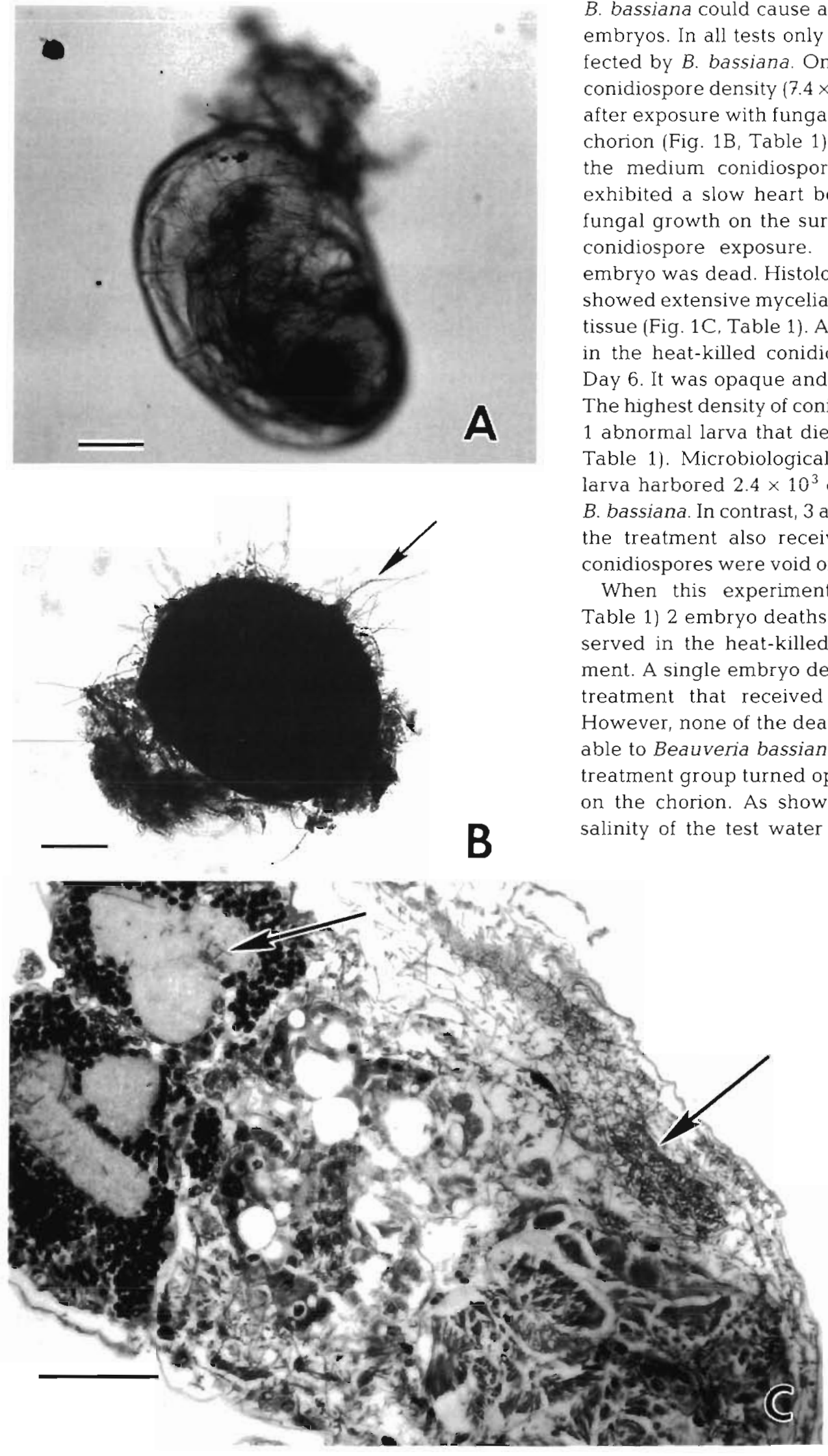

B. bassiana could cause adverse effects on developing embryos. In all tests only 2 exposed embryos were infected by $B$. bassiana. One embryo treated at the low conidiospore density $\left(7.4 \times 10^{3} \mathrm{ml}^{-1}\right)$ was found dead $9 \mathrm{~d}$ after exposure with fungal hyphae protruding from the chorion (Fig. 1B, Table 1). Another embryo, treated at the medium conidiospore density $\left(7.4 \times 10^{4} \mathrm{ml}^{-1}\right)$, exhibited a slow heart beat and possessed extensive fungal growth on the surface of the chorion $8 \mathrm{~d}$ after conidiospore exposure. On the following day this embryo was dead. Histological sections of this embryo showed extensive mycelial proliferation throughout the tissue (Fig. 1C, Table 1). A dead embryo was also found in the heat-killed conidiospore control treatment on Day 6. It was opaque and exhibited no fungal growth. The highest density of conidiospores in Expt 1 produced 1 abnormal larva that died shortly after hatch (Fig. 2, Table 1). Microbiological analysis revealed that this larva harbored $2.4 \times 10^{3}$ colony-forming units (cfu) of $B$. bassiana. In contrast, 3 apparently normal larvae from the treatment also receiving the highest density of conidiospores were void of $B$. bassiana.

When this experiment was repeated (Expt 2A, Table 1) 2 embryo deaths and a larval death were observed in the heat-killed conidiospore control treatment. A single embryo death was also recorded in the treatment that received the lowest spore density. However, none of the deaths in Expt $2 \mathrm{~A}$ were attributssiana; the dead embryo from the opaque with no fungal growth on the chorion. As shown in Expt 2B, reducing the salinity of the test water to $5 \%$ did not increase the

Fig. 1. Palaemonetes pugio. (A) Normal embryo $12 \mathrm{~d}$ post-fertilization. (B) Dead embryo, exposed since tissue cap stage to conidiospores of Beauveria bassiana (7.4 \pm $0.7 \times 10^{3}$ conidiospores $\mathrm{ml}^{-1}$ ), showing extensive fungal growth (arrow). (C) Histological section of a dead embryo with extensive mycelial growth throughout the tissues (arrows); H\&E. Bars = $0.2 \mathrm{~mm}$ in $A$ and $B, 0.1 \mathrm{~mm}$ in $\mathrm{C}$ 
Table 1. Palaemonetes pugio. Responses to conidiospores of Beauveria bassiana (GH) in Expts 1 \& 2

\begin{tabular}{|c|c|c|c|c|}
\hline \multicolumn{2}{|c|}{ Conidiospores $\mathrm{ml}^{-1}$} & \multirow[t]{2}{*}{ Sample size } & \multirow[t]{2}{*}{ Dead embryos } & \multirow{2}{*}{$\begin{array}{c}\text { Dead or abnormal } \\
\text { larvae }\end{array}$} \\
\hline Viable count & Direct count & & & \\
\hline \multicolumn{5}{|l|}{ Expt $1(20 \%$ salinity $)$} \\
\hline 0 (control) & 0 (control) & 25 & 0 & 0 \\
\hline $7.1 \pm 0.7 \times 10^{5}$ & $7.4 \pm 1.4 \times 10^{5}$ & 25 & 0 & 1 abnormal \\
\hline $7.1 \pm 0.7 \times 10^{4}$ & $7.4 \pm 1.4 \times 10^{4}$ & 25 & $1^{b}$ & 0 \\
\hline $7.1 \pm 0.7 \times 10^{3}$ & $7.4 \pm 1.4 \times 10^{3}$ & 25 & $1^{c}$ & 0 \\
\hline 0 (control, heat-killed $)$ & $7.4 \pm 1.4 \times 10^{5}$ & 25 & 1 & 0 \\
\hline \multicolumn{5}{|l|}{ Expt $2 \mathbf{A}(20 \%$ salinity) } \\
\hline 0 (control) & 0 & 25 & 0 & 0 \\
\hline $1.3 \pm 0.1 \times 10^{6}$ & $1.6 \pm 0.2 \times 10^{6}$ & 25 & 0 & 0 \\
\hline $1.3 \pm 0.1 \times 10^{5}$ & $1.6 \pm 0.2 \times 10^{5}$ & 25 & 0 & 0 \\
\hline $1.3 \pm 0.1 \times 10^{4}$ & $1.6 \pm 0.2 \times 10^{4}$ & 25 & 1 & 0 \\
\hline 0 (control, heat-killed) & $1.6 \pm 0.2 \times 10^{6}$ & 25 & 2 & 1 dead at hatch \\
\hline \multicolumn{5}{|l|}{ Expt 2B (5\%o salinity) } \\
\hline 0 (control) & 0 & 10 & 0 & 0 \\
\hline $1.3 \pm 0.1 \times 10^{6}$ & $1.6 \pm 0.2 \times 10^{6}$ & 10 & 0 & 0 \\
\hline
\end{tabular}

adverse effects from $B$. bassiana conidiospores; no deaths were observed in either the control or the experimental treatment (Table 1).

Expt 3A \& B investigated the effect of adding a carbon source for Beauveria bassiana (melezitose) to the test water. Salinities of 2 and $20 \%$ were tested. Examination of the spores in the water column after $48 \mathrm{~h}$ revealed that the spores did not germinate in the presence of $15 \mathrm{mg} \mathrm{l}^{-1}$ melezitose nor was increased spore germination on the surface of the chorion noted. However, after $5 \mathrm{~d}$ mycelia were observed adhering to the surface of several glass tubes at the air/water interface. The addition of melezitose encouraged bacterial growth. After $48 \mathrm{~h}$ more bacteria were found on the surface of the chorion in the presence of melezitose $\left(1.5 \times 10^{6}\right.$ embryo $\left.^{-1}\right)$ than in the absence of this sugar $\left(3.6 \times 10^{5}\right.$ embryo $\left.^{-1}\right)$. No adverse effects of $B$. bassiana conidiospores on developing shrimp embryos were observed when melezitose was added to the test water; the few embryo and larval deaths in the experimental and control treatments were not due to $B$. bassiana (data not shown).
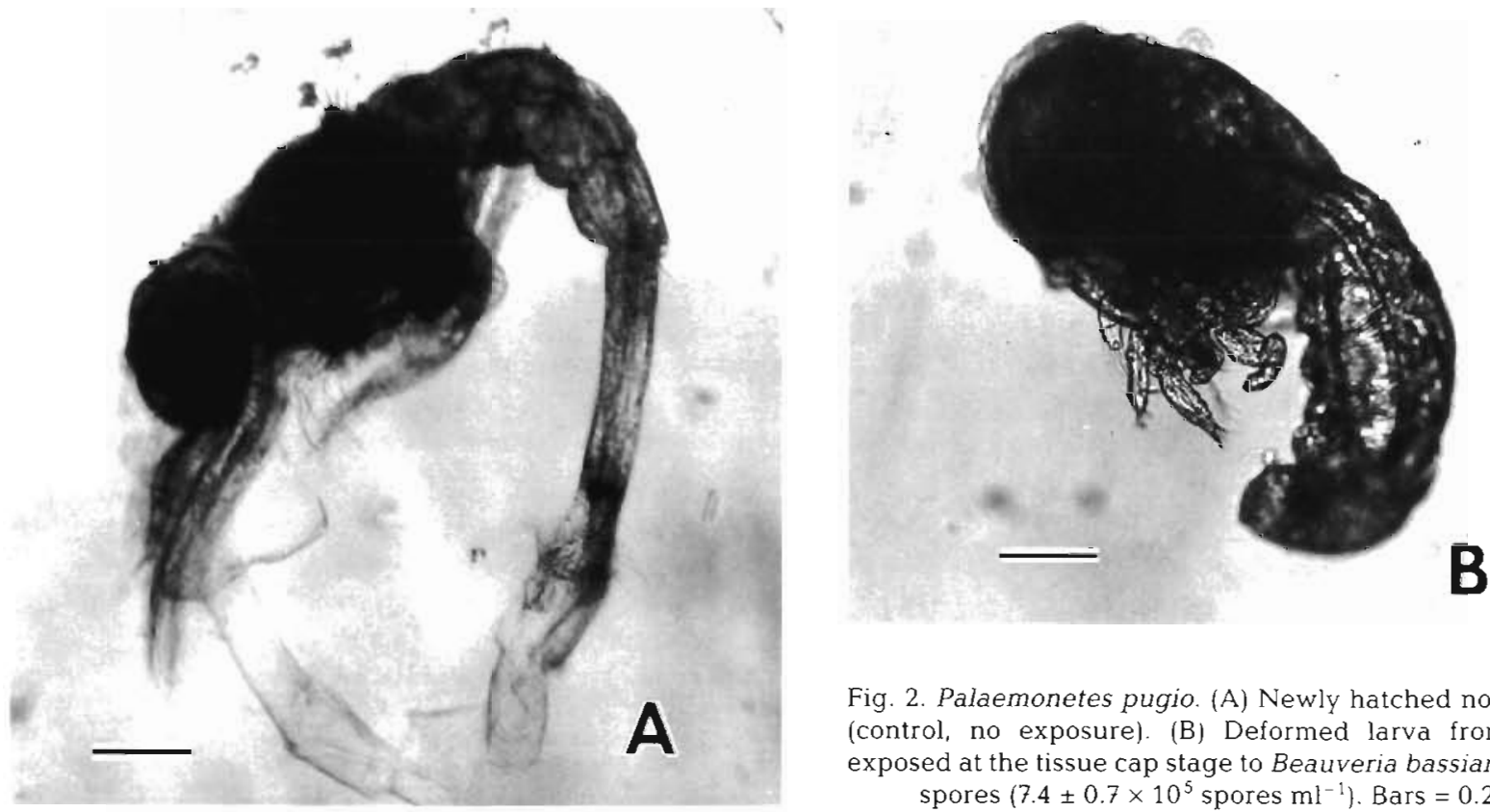

Fig. 2. Palaemonetes pugio. (A) Newly hatched normal larva (control, no exposure). (B) Deformed larva from embryo exposed at the tissue cap stage to Beauveria bassiana conidiospores $\left(7.4 \pm 0.7 \times 10^{5}\right.$ spores $\left.\mathrm{ml}^{-1}\right)$. Bars $=0.2 \mathrm{~mm}$ 
In Expt 4 developing shrimp embryos were rendered bacteria-free by incubating the embryos for $24 \mathrm{~h}$ in $\mathrm{Nx}$. After $9 \mathrm{~d}$, no culturable bacteria were found associated with the $\mathrm{Nx}$-treated embryos whereas the untreated embryos harbored $7.8 \times 10^{3}$ bacteria embryo ${ }^{-1}$ In this experiment only 1 embryo died, a control embryo (data not shown). Thus, exposure of bacteria-free embryos to Beauveria bassiana conidiospores produced no apparent adverse effects.

\section{Larval test}

In larval tests, $61 \%$ of larvae exposed to heat-killed conidiospores survived $23 \mathrm{~d}$ to metamorphosis. In the experimental bowls $48 \%, 68 \%$, and $46 \%$ survived in the high, medium, and low conidiospore densities, respectively. Thus, there were no significant differences ( $p \geq 0.01$ ) among treatments. In addition, microscopic examination of dead larvae did not reveal any evidence of fungal infection in dead larvae.

\section{Adult tests}

Conidiospores were found attached to embryos on gravid Palaemonetes pugio females. A gravid female exposed for $4 \mathrm{~h}$ to a conidiospore density of $8.6 \times 10^{5} \mathrm{ml}^{-1}$ (viable count), harbored $226 \pm 64$ conidiospores per 100 embryos. Conidiospore-exposed females placed under flow-through conditions possessed $394 \pm 36$ and $130 \pm 34$ conidiospores per 100 eggs after 2 and $6 \mathrm{~d}$, respectively.

After $7 \mathrm{~d}$ none of the adult shrimp exposed to Beauveria bassiana conidiospores in the aquarium water developed infections nor were there any mortalities.

Intrahemocoelic injections of $B$. bassiana conidiospores or blastospores produced high ( $\geq 95 \%$ ) mortalities (Table 2). Most mortalities occurred $48 \mathrm{~h}$ after injection. Microscopic examination of the hemolymph of moribund shrimp revealed that the B. bassiana spores had germinated and began growing within the specimen. Fungal hyphae were observed in numerous tissues and organs, including the hepatopancreas
(Fig. 3A); tail muscle (Fig. 3B); and gills (Fig. 3C). Heatkilled spores or a sterile filtrate from the spore suspension did not result in mortalities significantly higher than the saline-injection controls.

\section{DISCUSSION}

Adverse effects of Beauveria bassiana conidiospores on a nontarget crustacean test species were observed during water exposure to developing shrimp embryos and with intrahemocoelic injection of adults. Two embryos died in Expt 1 with strong evidence of fungal infection (Fig. 1). A third individual successfully hatched but appeared to be caught in the first larval ecdysis due to growth of filamentous fungal hyphae (Fig. 2) that restricted molting movements or separation of the exuvium. This affliction has also been observed with other Crustacea infected by fungi (Fisher et al. 1975). The remaining 72 embryos exposed to B. bassiana conidiospores in Expt 1 successfully hatched and molted without any evidence of fungal infection.

Several factors influence the infectivity of Beauveria bassiana spores including attachment and germination (Ferron 1978). Having observed that conidiospores readily attached to the embryo, we concentrated our efforts on factors that govern germination. Preliminary studies showed that conidiospore germination was markedly reduced in GYBS broth made with sea water at a salinity of $20 \%$ (data not shown). Thus, Expt $2 \mathrm{~B}$ was performed with a lower salinity to increase the potential for infectivity by $B$. bassiana. In addition, since washed conidiospores cannot germinate and grow in distilled water, the addition of a carbon-energy source to enhance germination (Smith \& Grula 1981) was examined in Expt 3. However, modifying the test water by reducing the salinity to $5 \%$ and adding melezitose, a carbon source readily utilizable by the fungus (Campbell et al. 1983), did not produce any evidence of infection.

Previous studies demonstrated that embryo susceptibility to fungal infections could be altered by the pres-

Table 2. Palaemonetes pugio. Mortality of specimens injected with spores of Beauvena bassiana. Dosage: $5 \times 10^{5}$ spores

\begin{tabular}{|c|c|c|c|c|c|c|c|c|c|c|}
\hline \multirow{2}{*}{ Injection } & \multirow{2}{*}{ No. tested } & \multicolumn{8}{|c|}{ Number dead } & \multirow{2}{*}{$\%$ Mortality } \\
\hline & & Day: & 1 & 2 & 3 & 4 & 5 & 6 & 7 & \\
\hline Control (saline) & 20 & & 0 & 0 & 0 & 0 & 0 & 0 & 0 & 0 \\
\hline Heat-killed conidiospores & 20 & & 1 & 0 & 0 & 0 & 1 & 0 & 0 & 10 \\
\hline Heat-killed blastospores & 20 & & 1 & 0 & 1 & 0 & 0 & 0 & 0 & 10 \\
\hline Filtrate from conıdiospore suspension & 15 & & 0 & 0 & 0 & 0 & 0 & 0 & 0 & 0 \\
\hline Conidiospores & 20 & & 1 & 15 & 3 & 0 & 0 & 0 & 0 & 95 \\
\hline Blastospores & 20 & & 0 & 17 & 1 & 0 & 0 & 1 & 0 & 95 \\
\hline
\end{tabular}


ence of indigenous bacterial flora with anti-fungal characteristics. Fisher (1983a) and Gil-Turnes et al. (1989) demonstrated that a bacterium of the genus Alteromonas protected embryos of the grass shrimp Palaemon macrodactylus from infection by the fungus Lagenidium callinectes. Antibiotic elimination of surface bacteria increased the susceptibility of $P$. macrodactylus embryos to fungal infection. However, in our study (Expt 4) elimination of surface bacteria with $\mathrm{Nx}$ did not produce infections of Palaemonetes pugio embryos exposed to Beauveria bassiana conidiospores.

Although the adverse effects found in this study were not statistically significant, they may nonetheless be biologically relevant. Our studies showed that conidiospores adhered to oviposited embryos for at least $6 \mathrm{~d}$, in spite of 'preening' of embryos by the female (Fisher 1983b). Since unexpected changes in virulence and germination have been reported with entomopathogenic fungi (Weiser 1982) it is possible that extended testing would reveal additional infections. Indeed, Genthner \& Middaugh (1992) and Middaugh \& Genthner (1994) reported highly variable effects of Beauveria bassiana on embryos of the fish Menidia beryllina.

Because larvae of estuarine crustaceans are particularly sensitive to microbial invasion (Rogers-Talbert 1948, Brady \& de la Vega 1992), Palaemonetes pugio was reared from hatch through successful completion of metamorphosis in a controlled environment in the presence of Beauveria bassiana. Mortalities were high in both the control and

Fig. 3. Palaemonetes pugio. Adult injected with $5 \times 10^{5}$ conidiospores of Beauveria bassiana. Histologic sections through grass shrimp; H\&E. Sections through (A) hepatopancreas, (B) muscle, (C) gill showing fungal hyphae infecting the tissues (arrows) $\times 375$
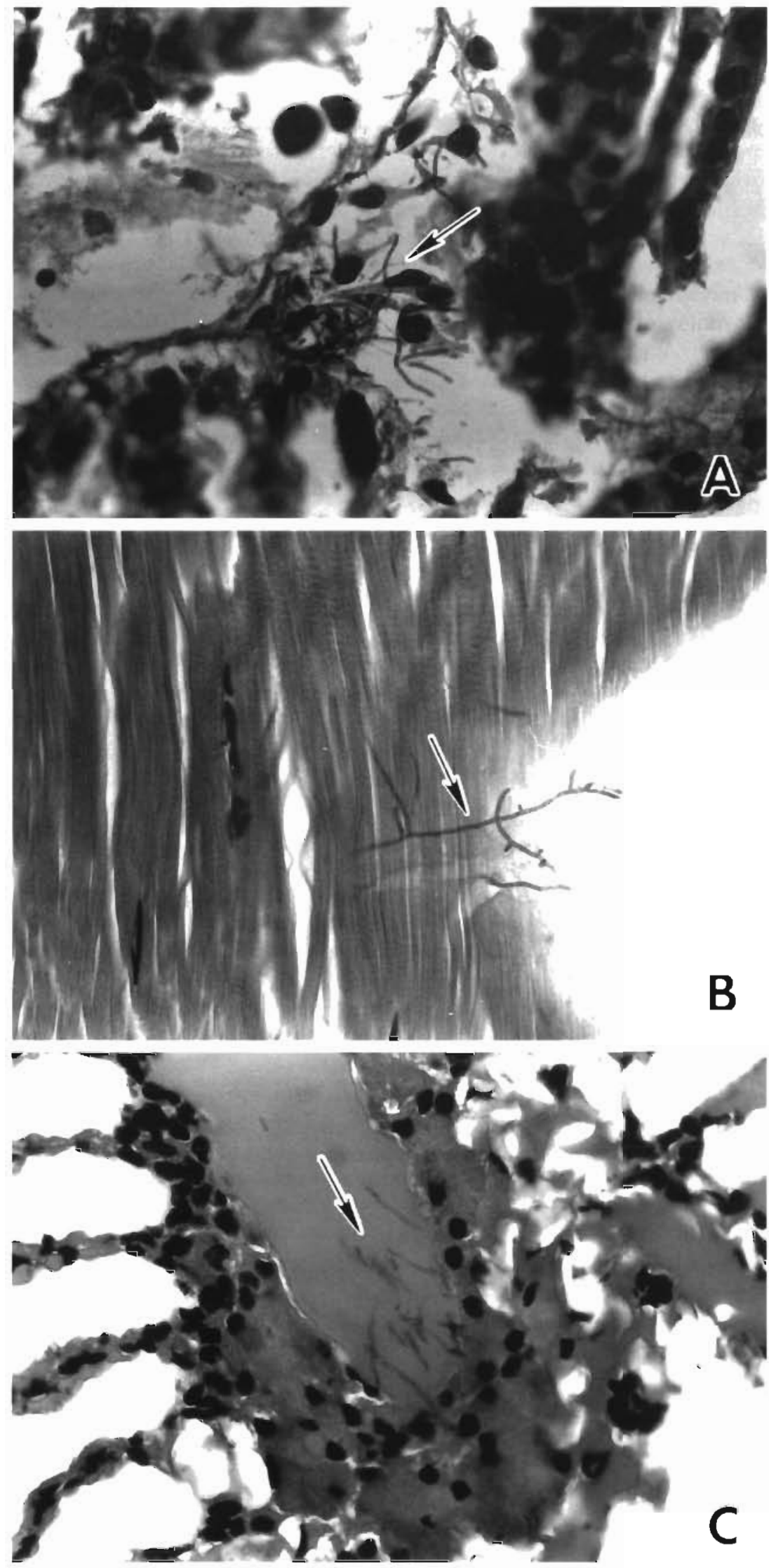
experimental treatments with considerable variability among replicate bowls. However, none of the mortalities were attributable to fungal infections as determined by microscopic examination of dead shrimp. Thus, the larval cuticle is apparently an effective barrier for this fungus

The fungi Lagenidium callinectes and Saprolegnia parasitica have been responsible for epizootics in shrimp larvae and embryos (Johnson 1983). In adult shrimp, a variety of fungi cause infections, but most have not been cultured or investigated. Fusarium solani is the exception as it has been responsible for mortalities in captive populations of several species of penaeids and 1 mortality in reared lobsters, Homarus americanus. Both normal and wounded penaeid shrimp were completely resistant to infection when held in aquaria containing $F$. solani spores. Death, however, occurred when spore dosages of $\geq 3.2 \times 10^{6}$ were injected. Mortality was most likely due to a mechanical blockage of the hemal sinuses of the gills (Solangi \& Lightner 1976).

Exposure of adult Palaemonetes pugio to conidiospores of Beauveria bassiana described here closely parallel the results that Solangi \& Lightner (1976) obtained with Fusarium solani. Specifically, experimental infections in adults were only observed with intrahemocoelic injections. The question remaining, with respect to microbial pest control agents, is whether $B$. bassiana can cause an epizootic in reared or wild populations of shrimp

Apparently, Palaemonetes pugio can be infected, albeit infrequently, or under extreme circumstances; it remains to be determined whether field release of Beauveria bassiana as a microbial pesticide would endanger natural populations of shrimp or other nontarget crustaceans.

\section{LITERATURE CITED}

Bidochka, M. J., Pfeifer, T A., Khachatourians, G. G. (1987). Development of the entomopathogenic fungus Beauveria bassiana in liquid cultures. Mycopathologia 99: 77-83

Boucias, D. G., Pendland, J. C., Latge, J. P. (1988). Nonspecific factors involved in attachment of entomopathogenic deuteromycetes in host insect cuticle. Appl. environ. Microbiol. 54: 1.795-1805

Brady, Y J., de la Vega, E. L. (1992). Recovery of Serratia marcescens in hemolymph of Macrobrachium rosenbergii from experimentally seeded water. J. World Aquacult. Soc. 23: 228-231

Campbell, R. K., Barnes, G. L., Cartwright, B. O., Eikenbary, R. D. (1983). Growth and sporulation of Beauveria bassiana and Metarhizium anisopliae in a basal medium containing various carbon sources. J. Invertebr Pathol. 41: $117-121$

Donegan, K., Lighthart, B. (1989). Effect of several stress factors on the susceptibility of the predatory insect, Chrysoperia carnea (Neuroptera: Chrysopidae), to the fungal pathogen Beauveria bassiana. J. Invertebr. Pathol. 54: $79-84$

Ferron, P. (1978). Biological control of insect pests by entomogenous fungi. A. Rev. Entomol. 23: 409-442

Fisher, W. S. (1983a). Eggs of Palaemon macrodactylus: III infection by the fungus, Lagenidium callinectes. Biol. Bull. 164: $214-226$

Fisher, W. S. (1983b). Eggs of Palaemon macrodactylus: II. association with aquatic bacteria. Biol. Bull. 164: 201-213

Fisher, W. S., Foss, S. S. (1993). A simple test for toxicity of number 2 fuel oil and oil dispersants to embryos of grass shrimp, Palaemonetes pugio. Mar. Pollut. Bull. 26: 385-391

Fisher, W. S., Nilson, E. H., Shleser, R. A. (1975). Effect of the fungus Haliphthoros milfordensis on the juvenile stages of the American lobster Homarus americanus. J. Invertebr. Pathol. 26: 41-45

Genthner, F. J., Cripe, G. M., Crosby, D. J. (1994). Effect of Beauveria bassiana and its toxins on Mysidopsis bahia (Mysidacea). Archs. environ. Contam. Toxicol. 26: 90-94

Genthner, F. J., Middaugh, D. P. (1992). Effects of Beauveria bassiana on embryos of the inland silverside fish Menidia beryllina. Appl environ. Microbiol. 58: 2840-2845

Gil-Turnes, M. S., Hay, M. E., Fenical, W. (1989). Symbiotic marine bacteria chemically defend crustacean embryos from a pathogenic fungus. Science 246: 117-118

James, R. R., Lighthart, B. (1994). Susceptibility of the convergent lady beetle to four entomopathogenic fungi. Environ Entomol, 23: 188-190

Johnson, P. T (1983). Diseases caused by viruses, rickettsiae bacteria, and fungi. In: Provenzano, A. J. (ed.) The biology of Crustacea. Vol. 6. Academic Press, New York, p. 1-78

Khachatourians, G. G. (1986). Production and use of biological pest control agents. Trends Biotechnol. 4: 120-124

Luna, L. G. (1968). Manual of histologic staining methods of the Armed Forces Institute of Pathology, 3rd edn. McGraw-Hill, New York, p. 5, 32 \& 222

McCoy, C. W. (1990). Entomogenous fungi as microbial pesticides. In: Baker, R. R., Dunn, P. E. (eds.) New directions in biological control: alternatives for suppressing agricultural pests and diseases. Alan R. Liss, New York, p. $139-159$

McKenney, C. L., Neff, J. M. (1979). Individual effects and interactions of salinity, temperature and zinc on larval development of the grass shrimp, Palaemonetes pugio. Survival and developmental duration through metamorphosis. Mar. Biol. 52: 177-188

Middaugh, D. P., Genthner, F. J. (1994). Infectivity and teratogenicity of Beauveria bassiana in Menidia beryllina embryos. Archs environ. Contam. Toxicol. 27: 95-102

Osborne, L. S., Landa, Z. (1992). Biological control of whiteflys with entomopathogenic fungi. Fla Entomol. 75: 456-471

Rogers-Talbert, R. (1948). The fungus Lagenidium callinectes Couch (1942) on eggs of the blue crab in Chesapeake Bay. Biol. Bull, 95: 214-228

SAS Institute Inc. (1985). SAS user's guide: statistics, version 5 edn. SAS Institute Inc., Cary, NC

Shaw, B. L., Battle, H. I. (1957). The gross and microscopic anatomy of the digestive tract of the oyster Crassostrea virginica (Gmelin). Can. J. Zool. 35: 325-347

Sindermann, C. J. (1990). Principal diseases of manine fish and shellfish, Vol. 2, 2nd edn. Academic Press, New York

Smith, R. J., Grula, E. A. (1981). Nutritional requirements for conidial germination and hyphal growth of Beauveria bassiana. J. Invertebr. Pathol. 37: 222-230

Solangi, M. A., Lightner, D. V. (1976). Cellular inflammatory response of Penaeus aztecus and $P$. setiferus to the patho- 
genic fungus, Fusarium sp., isolated from the California brown shrimp, $P$. californiensis. J. Invertebr. Pathol. 27: $77-86$

Sparks, A. K. (1985). Synopsis of invertebrate pathology exclusive of insects. Elsevier Science Publishers, Amsterdam

Weiser, J. (1982). Persistence of fungal insecticides: influence of environmental factors and present and future applica-

Responsible Subject Editor: O. Kinne, Oldendorf/Luhe, Germany tions In: Kurstak, E. (ed.) Microbial and viral pesticides Marcel Dekker, New York, p. 531-557

Wilson, J. E. H. (1985). Sublethal effects of diflubenzuron (Dimilin) on the reproduction and photobehavior of the grass shrimp Palaemonetes pugio Holthius (Caridea. Palaemonidae). Ph.D. dissertation, Duke University. Durham, NC

Manuscript first received: February 2, 1994

Revised version accepted: July 12, 1994 